\title{
Customer Satisfaction and Customer Loyalty in the Post-Crisis Banking Sector of Ghana
}

\author{
Frank Boateng $^{1 *} \quad$ Michael Adesi $^{2} \quad$ Edward Yeboah $^{3} \quad$ Linda Maysel Oduro $^{3} \quad$ Margaret Mary Sackey $^{1}$ \\ 1.Management Studies Department, Faculty of Integrated Management Science, University of Mines and \\ Technology, Tarkwa, Ghana PO Box 237, Tarkwa, Ghana \\ 2.Department of Construction Technology and Management, College of Art and Built Environment, Faculty of \\ Built Environment, Kwame Nkrumah University of Science and Technology, Kumasi, Ghana. Post Office Box \\ PMB, KNUST, Kumasi, Ghana \\ 3.Institute of Distance Learning (IDL), Kwame Nkrumah University of Science and Technology, \\ Kumasi, Ghana. Office Box PMB, KNUST, Kumasi, Ghana
}

\begin{abstract}
The banking industry is immensely important to the socio-economic development of emerging economies by facilitating the exchange of money between depositors and borrowers. The banking industry in Ghana is facing corporate governance challenges, which has led to non-performance and subsequent withdrawal of operating licenses. The withdrawal of the licenses by the Bank of Ghana has impact on customer loyalty and satisfaction, which has not been significantly investigated in a post crisis banking sector of Ghana. This has resulted in many companies undertaking numerous product design and innovation to satisfy customers. This study therefore is aimed at investigating the relationship between customer satisfaction and customer loyalty in the post crisis banking sector of Ghana. The study adopts the positivist traditional stance with a quantitative approach. Participants were drawn from among the customers of universal banks in Ghana. The purposive sampling technique was used to administer 250 questionnaires to customers of universal banks in Ghana in which 170 usable questionnaires were retrieved for analysis with a response rate of 68 per cent. The investigation revealed that customer satisfaction variables have significantly influenced the loyalty of customers of banks involved in this study. The results indicated that tangibles, reliability, responsiveness, assurance and empathy, and dimensions of service quality have positive influence on customer satisfaction. The investigation largely focused on quantitative analysis of results, hence; a further study adopting the qualitative approach would contribute to the body of knowledge on customer loyalty and satisfaction in the banking sector. This study provides a strong evidence for banks that have been negatively impacted by the banking crisis in Ghana and want to recover from the associated impacts on their customers to enhance their customer satisfaction by improving the tangibility and reliability of services to clients. It is recommended that Banks in Ghana focus on achieving high customer satisfaction by focusing on high quality services delivery based on the service quality dimensions.
\end{abstract}

Keywords: Banking, Industry, Customer, Satisfaction, Loyalty

DOI: $10.7176 / \mathrm{JMCR} / 76-04$

Publication date: February $28^{\text {th }} 2021$

\section{Introduction}

Customer satisfaction contributes significantly to the retention of existing customers and improves their loyalty for repeat business (Kotler and Keller, 2006). Many organisations depend on the satisfaction of their customer to assess the performance of their service delivery through feedback (Nimako, 2012). Customer satisfaction deals with contentment; and meeting the expectations of buyers (Giese and Cote, 2000). Customer satisfaction also focuses on organisational processes for satisfying clients' needs (Mukerjee, 2013). The psychological dimensions of customer satisfaction have been noted in existing literatures demonstrating the perceived satisfaction of customers and the ability of organisations to meet or exceed their expectations regarding a product (Liu and Liu, 2020).

Customers tend to evaluate their satisfaction by discrepancies service delivery to their prior expectations and the functional performance of the product/service (Chang et al., 2020). The gap in a customer's emotional response and assessment of perceived service quality and original expectations are critical to ascertaining customer satisfaction (Anwar et al., 2019). Similarly, product performance affects customers' satisfaction, which also tends to affect customer loyalty (Kotler and Armstrong, 2012).

Customer loyalty is an attitude-based phenomenon demonstrated by people who transact business with organisations (Uncles et al., 2003). Customer loyalty is the outcome of meeting buyer's satisfaction by companies in order to ensure repeat business (Fifield, 2008). The degree of a customer's re-purchase behavior towards a service provider is also critical to achieving customer loyalty by business organisations (Gremler and Brown, 1996). Customer loyalty is affected by the proportion of times a purchaser chooses the same product or service in a specific category compared to the total number of purchases made by the purchaser in that category, under the condition that other acceptable products or services are conveniently available in that category (Neal, 
1999).

Though Tweneboah-Koduah and Farley (2016) investigate customer satisfaction and customer loyalty in retail banking sector of Ghana, their study focuses on participants selected from 27 different banks, which make their study population heterogenous. However, this study explores the relationship between customer satisfaction and customer loyalty from a post banking crisis dimension in Ghana. The post crisis perspective of this paper enables existing banks that are facing customer satisfaction challenges to use the variables involved in this study to improve their customers' satisfaction and loyalty. Again, an investigation by Narteh and Kuada (2014) on customer satisfaction with retail banking services in Ghana target participants drawn from 16 banks; and did not consider customer loyalty, which is a critical component of customer satisfaction. This study proposes to ascertain the relationship between customer satisfaction and customer loyalty in a post crisis banking sector of Ghana. Similarly, Nimako et al. (2013) explored customer satisfaction with emphasis on internet banking without considering all the services provided by the target banks involved in their study. Thus, this paper focuses on majority of services offered by banks in Ghana in order to develop a holistic viewpoint of customer satisfaction in the banking sector of Ghana, as demonstrated by this study.

In addition to the theoretical gaps in the studies undertaken on customer satisfaction in the banking sector of Ghana, the recent banking crisis which led to the revocation of licenses of non-compliant universal banks by the Bank of Ghana is largely due to poor corporate governance. The subsequent closure of non-compliant universal banks in Ghana has a negative effect on customer satisfaction in the banking sector. Thus, this investigation is essential to banks operating in Ghana as it seeks to ascertain the loyalty and satisfaction of customers. The banking crisis reduced the number of banks operating in Ghana from 34 to 24 banks indicating the irregularities that led to revocation of licenses has the potential to affect customer satisfaction and loyalty of clients to the existing banks. The aim of this study is to ascertain the linkage between customer satisfaction and customer loyalty in the post crisis banking sector of Ghana.

\section{Literature Review}

Customer satisfaction is considered, as the baseline standard of performance and a possible standard of excellence for any business organisation (De Bruin et al., 2020). Customer satisfaction involves product performance attributes such as technical sophistication; durability; user friendly; and the judgment based on the interpersonal interaction between the sales representative and the customer to meet a customer's needs (Tech, 2020). Several explanations have been proffered by scholarly investigations on customer satisfaction. The commonality in these explanations of customer satisfaction relates to the experiences of buyers in terms of product quality; expectations about the product performance; and prior experiences of individuals before interacting with the product (Solomon et al., 2006). The definitions of customer satisfaction demonstrate its complexity. This makes it difficult for organisations to understand the basic requirements, of customer satisfaction, which is underpinned by the feelings and emotions of customers (Fifield, 2008). Existing body of knowledge shows that the measurement of customer satisfaction should focus on a person's feeling of pleasure, disappointment or indifference that affect the purchase of the product or service (Esbjerg et al., 2012).

Though product performance is a critical factor to customer satisfaction, investigation by Solomon et al. (2006) demonstrates the need to address the hedonic performance of products, and not only functional performance. The hedonic performance of products refers to the tangible attributes of a product that have positive influence on customer satisfaction (Ladeira et al., 2016). The tangible attributes of products that influence customer satisfaction include store cleanliness, sales areas, variety of product displays, lighting, colour, and the sales team (Mitchell and Harris, 2005). The ease of finding products also forms part of the tangible attributes (Ladeira et al., 2016), which also includes the availability or visibility of banking services to customers is investigated in this paper. Similarly, tangibility in the banking sector is demonstrated by the aesthetic appeal, the use of modern equipment; technology adoption; and appearance of employees in the banking premises (Tuzovic, 2008). In another development, tangibles within the banking industry involve ambient conditions such as temperature, ventilation, noise, and scent prevailing in the bank's premises; arrangement of equipment; and signs and symbols to direct customers (Barber and Scarcelli, 2010).

The increasing level of technological disruption affects the key components of customer satisfaction in the banking sector (Reimer and Kuehn, 2005). For instance, the increasing use of digital technologies leads to the evolution of electronic banking and the ability of banks to provide services to clients in different parts of the world (Al-Eisa and Alhemoud, 2009). ATM installations, electronic funds transfers (EFTs), credit cards, and point-of-sale (POS) devices adopted by banks enable customers to transact business from various locations without physical presence at the banking premises influences the level of customer satisfaction (Narteh and Kuada, 2014). The use of technology to promote electronic banking leads to self-banking with positive impacts on customer satisfaction (Al-Eisa and Alhemoud, 2009).

The importance of customer satisfaction has been discussed in the studies undertaken by Solomon et al. (2006); and Kotler and Armstrong (2012) in which they note repeat business; spreading goodwill of the firm by 
word-of-mouth; and paying less attention to competing brands and advertising. On the contrary, dissatisfied customers spread negative or bad word-of-mouth which damages the reputation of the firm.

Many factors account for customer satisfaction in firms. According to Reid and Sanders (2011) factors such as product design and quality; competitive pricing, and ability of products/services to fulfill market need promote customer satisfaction. Factors such as cycle time and timely delivery of products contribute to service quality, which enhances customer satisfaction (Samudro et al., 2020).

With regards to service quality, Hanson (2000) and Zairi (2000) note that enhancing service quality dimensions such tangibles, empathy, responsiveness, reliability and assurance enable firms to meet customers' needs and expectations. This study adopts service quality dimensions: reliability, responsiveness, assurance, empathy and tangibles in measuring the satisfaction of customers. customers' choice of product depends on factors such as quality, type of product, price, and locational convenience (Szuts and Tóth, 2008). Thus, organisations must focus on improving the factors that influence customers' choice of products in order to ensure customer loyalty.

\section{Customer Loyalty}

Customer loyalty is a commitment to consistently re-buy a product or service in the future despite the availability of competing products (Oliver, 1997). Loyal customers are less likely to switch to competitor product no matter their unique appeal (Tweneboah-Koduah and Farley, 2016). Diverse definitions of customer loyalty, which emphasise attitude or and other behavioural dimensions of the customer (Dick and Basu 1994). Behavioural loyalty involves elements such as the frequency of calls, the level of cross selling and buying, and the length of the relationship (Liu-Thompkins and Tam, 2013; and Bobâlca, 2013). In a fast-moving consumer market, behavioural loyalty measures are better placed in predicting loyalty than attitudinal measures (Pabbi and Narula, 2020). Customers first become loyal in a cognitive sense due to their believe in the brand, followed by the affective sense and, lastly, loyalty is exhibited in the form of action in which the intent is turned into behaviour (Nordman, 2004).

Attitudinal loyalty comprises of a consumer's desire to continue the relationship with the company and recommend the product to friends despite the lower prices of the competing companies (Dick and Basu, 1994). The definitions of customer loyalty reflect repeat patronage; commitment; fidelity and friendship; affirmative temperament; and long-term relationship (Durukan and Bozaci, 2011), which have not been explored in the post banking crisis sector of Ghana. Customer loyalty in the banking industry is a challenge to many retail bankers due to their inability to adopt appropriate strategies to optimise customer satisfaction (Mandhachitara and Poolthong, 2011; Szuts and Tóth, 2008). However, loyalty programmes developed by retail banks to reward customers for using their products do not necessarily enhance customer loyalty. Drawing from the review of existing literature so far, it is appropriate to hypothesized that: customer loyalty is significantly dependent on the following drivers of customer satisfaction in banks: (H1) Tangibles; (H2) Reliability; (H3) Responsiveness; (H4) Assurance; (H5) Empathy.

\section{Research Methodology}

This study is entrenched in the positivist philosophical tradition. The positivist tradition uses the methods of natural sciences to investigate social phenomenon. This assertion is consistent with the position of Crotty (1998) that positivism applies the method of natural sciences such as the quantitative approach and hypotheses testing to discover social phenomenon. In order to test the hypothesis formulated for this investigation, the quantitative research approach was adopted. The questionnaire deals with two main issues notably, customer satisfaction and its relationship with the self-perceived assessment of service quality of banking services provided by the twentythree banks involved in the study. The second part of the questionnaire involves customer loyalty, which measures variables such as tangibles, reliability, responsiveness, assurance and empathy, which are measured using a five-point likert scale. The questionnaire consists of both open-ended and closed-ended questions, which were formulated using simple words to enhance participants' understanding. Closed-ended questions were used because they are easy to answer, and do not require lot of time to answer. The reliability of the scale of measurement was ascertained by using the Cronbach Alpha for the constructs shown in Table 1.

Table 1: Reliability test

\begin{tabular}{lcc}
\hline \multicolumn{1}{c}{ Constructs and Variables } & Cronbach Alpha & Number of Items \\
\hline 1. Tangibles & 0.74 & 5 \\
2. Reliability & 0.77 & 6 \\
3. Responsiveness & 0.80 & 5 \\
4. Assurance & 0.84 & 4 \\
5. Empathy & 0.83 & 4 \\
6. Customer satisfaction & 0.89 & 5 \\
7. Customer loyalty & 0.78 & 9 \\
\hline
\end{tabular}


The Cronbach Alpha values of the constructs in Table 1 indicate a high internal consistency since the values are above 0.7 , demonstrating that the questionnaire measured the intended constructs and variables involved in the investigation. In terms of data analysis, the Statistical Package for Service Solutions computer software version 20.0 was used to organise the data in which the Pearson Correlation statistic was used to ascertain the relationship between customer satisfaction and customer loyalty in the banking sector of Ghana.

The population of the study consist of customers of the twenty-three (23) licensed universal banks in Ghana In using the purposive sampling technique, 400 questionnaires were administered to participants using an online mediated platform. The purposive sampling ensures the selection of respondents with the requisite information related to the investigation. At the end of the instrument administration, 250 usable questionnaires were retrieved for analysis with a response rate of 63 per cent.

\section{Analysis and Discussion of Results}

This section focuses on the analysis and discussion of results obtained from the administration of survey questionnaires to participants involved in the investigation. The analysis focuses on testing the hypothesis formulated during the review of existing literature. The hypothesis sought to establish the relationship between customer loyalty and variables related to customer satisfaction. The null hypothesis is denoted by $\mathrm{H}_{0}$ while the alternate hypothesis is represented by $\mathrm{H}_{1}$ below:

$H_{0}$ : Customer loyalty is not significantly dependent on the following drivers of customer satisfaction in banks:

(H1) Tangibles; (H2) Reliability; (H3) Responsiveness; (H4) Assurance; (H5) Empathy.

$H_{1}$ : Customer loyalty is significantly dependent on the following drivers of customer satisfaction in banks:

(H1) Tangibles; (H2) Reliability; (H3) Responsiveness; (H4) Assurance; (H5) Empathy.

Table 2 shows the result pertaining to the null hypothesis testing. The result shows that there is a significant relationship between customer loyalty and the drivers of customer satisfaction notably, tangibles, reliability, responsiveness, assurance, and empathy at a $p$-value less than 0.01 .

Table 2: Factors influencing customer satisfaction

\begin{tabular}{lccc}
\hline Independent Variables & Correlation Coefficient & $\boldsymbol{p}$-value & Decision \\
\hline 1. Tangibles & 0.863 & $\mathbf{0 . 0 1}$ & Reject \\
2. Reliability & 0.884 & $\mathbf{0 . 0 1}$ & Reject \\
3. Responsiveness & 0.861 & $\mathbf{0 . 0 1}$ & Reject \\
4. Assurance & 0.723 & $\mathbf{0 . 0 1}$ & Reject \\
5. Empathy & 0.837 & $\mathbf{0 . 0 1}$ & Reject \\
\hline
\end{tabular}

The result in Table 2 indicates that tangibility positively drives satisfaction, as it has a Pearson Correlation statistic of 0.863 , demonstrating a strong relationship between customer satisfaction and loyalty. Considering the correlation coefficient, Table 2, tangibles are the second most essential factor that influence the satisfaction of customers involved in the study. Tangibles in this regard are driven by factors such as the design, layout, amount of space in the banking hall, and type of furniture for customers. Similarly, facilities for comfortability such as television set, ATM and air-conditioning units have the potential to enhance the tangibility of services provided by the banks involved in this study.

With regards to reliability, the result in Table 2 revealed a Pearson correlation coefficient of 0.884 at a significance level of 0.01 , indicating an increase in the provision of reliable services in banks involved in the investigation leads to an improved customer satisfaction. Similarly, this result is consistent with the alternate hypothesis by emphasizing that reliability is positively related to customer satisfaction. Reliability is a service quality dimension, which influences customer satisfaction of participants involved in the research. Considering the correlation coefficients in Table 2, the study found that reliability ensures the highest level of customer satisfaction in banks involved in this investigation. Banks that intend to enhance satisfaction and loyalty of their customers in the post crisis banking sector of Ghana must adopt measures that improve the trust, dependability, quality and efficient delivery of services by employees.

The responsiveness of banks to the needs of their customers influences customer satisfaction and demonstrate the quality of banking services offered to clients. The results in Table 2 show correlation coefficient of 0.861 for responsiveness at a significance level of 0.01 . This means that there is a positive relationship between responsiveness and customer satisfaction; and that majority of the customers involved in this investigation perceive their banks to be highly responsive to their needs. Considering the magnitude of the correlation statistics in Table 2, responsiveness is the third most important driver of customer satisfaction among the participants involved in this research. The key issues influencing the responsiveness of banks involved the study in a post crisis banking sector include prompt response to service disruptions, and the ability of the banks to swiftly notify their customers. Notable among the service disruptions experienced by customers of banks in Ghana include malfunctioning ATMs, and their location at unsuitable places where customers find it difficult to access them. The banks address the challenges of service disruptions by introducing ATM cards to replace overdependence on cheque books and placing signs to direct customers to ATM locations. Similarly, customers 
must be provided with regular update and information on the availability and maturity of financial products; account activities and details that help reduce costs, reduce stress, discomfort and disappointments in order to enhance their satisfaction and loyalty.

The research found that assurance has a positive influence on customer satisfaction ratings of the banks involved in the investigation. For instance, Table 2 shows that assurance has a correlation coefficient of 0.723 , at 0.01 significance, indicating a strong positive relationship between assurance and customer satisfaction. This positive relationship demonstrates that customer perception of bank assurance factors such as safety of transactions; employee courtesy and employees' knowledge are prevalent in the banks involved in the research. The result also shows in Table 2, that empathy has a correlation coefficient of 0.837 at a significance of 0.01 . This shows that empathy has a positive influence on customer satisfaction. Empathy deals with bank employees' ability to understand the needs of customers in order to address them without discrimination.

The study identifies five main drivers of customer satisfaction, which leads to customer loyalty. These drivers include tangibles; reliability; responsiveness; assurance; and empathy. These factors have significant positive impact on customer satisfaction by offering customers service quality and physical evidence to meet customer expectations. Overall, the study found that service quality dimensions including tangibles, reliability, responsiveness, assurance and empathy are positively related to customer satisfaction. This finding is consistent with the views of Oliver (1997) who reported that service quality is a contributory antecedent of customer satisfaction.

\section{Conclusion}

The aim of this study is to investigate the relationship between customer satisfaction and customer loyalty within the banking industry of Ghana, which has been confronted with noncompliance and closure of banks. The crisis in the banking sector of Ghana has the potential to affect the perception of customers couple with the dire consequences of low customer satisfaction. This study demonstrates that the universal banks involved in this study can address the challenges of customer satisfaction and loyalty by improving upon their five main dimensions of their service provision. These dimensions include service tangibility, reliability, responsiveness, assurance and empathy, which have the potential to driver customer satisfaction and loyalty. It is therefore necessary for banks in Ghana to design products that address these five main drivers of customer satisfaction, which have been explored in this investigation. Also, need-based product design must form the nucleus of the banks' strategy in order to improve the confidence, satisfaction and loyalty of customer. Thus, the banks must undertake research and development to make them innovative in the design of new products that address the five critical areas of customer satisfaction examined in this study.

\section{References}

Al-Eisa, A. S. and Alhemoud, A. M. (2009), "Using a multiple attribute approach for measuring customer satisfaction with retail banking", International Journal of Bank Marketing, Vol. 27, No. 4, pp. $294-314$.

Anwar, S., Min, L. and Dastagir, G. (2019), "Effect of Service Quality, Brand Image, Perceived Value on Customer Satisfaction and Loyalty in the Chinese Banking Industry", International Journal of Business, Economics and Management Works, Vol. 6, No. 3, pp. 24-30.

Barber, N. and Scarcelli, J. M. (2010).,"Enhancing the assessment of tangible

service quality through the creation of a cleanliness measurement scale", Managing Service Quality, Vol. 20, No. 1, pp. $70-80$.

Bobâlca, C. (2013), : "Study of Customers' Loyalty: Dimensions and Facets", Management and Marketing, Vol. XI, No. 1, pp. 7-20.

Cottet, P., Lichtle, M. C. and Plichon, V. (2006), "The Role of Value in Services: A Study in a Retail Environment", Journal of Consumer Marketing, Vol. 23, No. 4, pp. 219-227.

Chang, A. C., Trappey, C. V., Trappey, A. J. and Chen, L. W. (2020), "Web Mining Customer Perceptions to Define Product Positions and Design Preferences", International Journal on Semantic Web and Information Systems (IJSWIS), Vol. 16, No. 2, pp. 42-58.

Crotty, M. (1998). The foundations of social research: meaning and perspective in the research process, St Leonards: Allen \& Unwin.

De Bruin, L., Roberts-Lombard, M. and De Meyer-Heydenrych, C. (2020), "Internal marketing, service quality and perceived customer satisfaction: An Islamic banking perspective", Journal of Islamic Marketing, Vol. ahead-of-print No. ahead-of-print. https://doi.org/10.1108/JIMA-09-2019-0185

Dick, A. S., and Basu, K. (1994), "Customer loyalty: toward an integrated conceptual framework", Journal of the Academy of Marketing Science, Vol. 22, No. 1, pp. 99-113.

Durukan, T. and Bozaci, I. (2011), "The Role of Individual Characteristics on Customer Loyalty", International Journal of Business and Social Science, Vol. 2, No. 23, pp. 23-40

Esbjerg, L., Jensen, B. B., Bech-Larsen, T., de Barcellos, M. D., Boztug, Y. and Grunert, K. G. (2012), “An 
integrative conceptual framework for analyzing customer satisfaction with shopping trip experiences in grocery retailing”, Journal of Retailing and Consumer Services, Vol. 19, No. 4, pp. 445-456.

Fifield, P. (2008), Marketing Strategy Masterclass: Implementing Strategy, first edition, Amsterdam, Elsevier Limited.

Giese, J.L. and Cote, J.A. (2000), “Defining Consumer Satisfaction”, Academy of Marketing Science Review, Vol. 4, No. 1, pp. 1-24

Gremler, D.D. and Brown, S.W. (1996), "Service loyalty: its nature, importance, and implications", Advancing service quality: A global perspective, Vol. 5, No. 1, pp.171-181.

Kotler, P. and Keller, K. (2006), Marketing Management, 12th edition., New Jersey, Pearson Education Inc.

Ladeira, W.J., Nique, W.M., Diego Costa Pinto, D.C. and Borges, A. (2016), "Running for pleasure or performance? How store attributes and hedonic product value influence consumer satisfaction", The International Review of Retail, Distribution and Consumer Research, Vol. 26, No. 5, pp. 502-520.

Liu, X-Y. and Liu, Y. (2020), "The service smile chain: linking leader emotions to customer outcomes", The Service Industries Journal, Vol. 40, No. :5-6, pp. 415-435.

Liu-Thompkins, Y. and Tam, L. (2013), "Not all repeat customers are the same: Designing effective crossselling promotion on the basis of attitudinal loyalty and habit", Journal of Marketing, Vol. 77, No. 5, pp. 21-36.

Mukerjee, K. (2013), "Customer-oriented organizations: a framework for innovation", Journal of Business Strategy, Vol. 34, No. 3, pp. 49-56.

Mitchell, V. and G. Harris. (2005), "The Importance of Consumers Perceived Risk in Retail Strategy", European Journal of Marketing, Vol. 39, No. 7/8, pp. 821-837.

Narteh, B. and Kuada, J. (2014), "Customer satisfaction with retail banking services in Ghana", Thunderbird International Business Review, Vol. 56, No. 4, pp. 353 - 371.

Neal, W.D. (1999), "Satisfaction is Nice, but Value drives Loyalty", Marketing Research, Vol. 11, No. 1, pp. 2023.

Nimako, S. G., Gyamfi, N. K. and Wandaogou, A. M. M. (2013), "Customer satisfaction with internet banking service quality in the Ghanaian banking industry", International Journal of Scientific \& Technology Research, Vol. 2, No. 7, pp. 165-175.

Nimako, S.G. (2012), "Linking Quality, Satisfaction and Behaviour Intentions in Ghana's Mobile Telecommunication Industry”, European Journal of Business Management, Vol. 4, No. 7, pp. 1-17.

Nordman, C. (2004), "Understanding customer loyalty and disloyalty: the effect of loyalty-supporting andrepressing factors". Publications of the Swedish School of Economics and Business Administration.

Oliver, R. L. (1977), "Effects of expectation and disconfirmation on post-exposure product evaluations: An alternative interpretation", Journal of Applied Psychology, Vol. 62, No. 4, pp. 480-486.

Pabbi, T. and Narula, S. (2020), "Effects of Antecedents on Behavioural and Attitudinal Loyalty in Quick Service Restaurant", Our Heritage, Vol. 68, No.30, pp. 6800-6815.

Reid, D.R. and Sanders, N.R. (2011), Operations Management; An integrated Approach, $4^{\text {th }}$ Edition, John Wiley and Sons Inc, New Jersey, USA.

Reimer, A. and Kuehn, R. (2005), “The impact of service scape on quality perception”, European Journal of Marketing, Vol. 39, No. 1, pp. 785-808.

Samudro, A., Sumarwan, U., Simanjuntak, M. and Yusuf, E. (2020), “Assessing the effects of perceived quality and perceived value on customer satisfaction”, Management Science Letters, Vol. 10, No. 5, pp. 1077-1084.

Solomon, M., Bamossy, G., Askegaard, S. and Hogg, M.K. (2006). Consumer Behaviour A European Perspective, 3rd Edition, Edingburg: Prentice Hall.

Szuts, I. and Tóth, Z. (2008), Customer Loyalty Problems in Retail Banking. MEB $2008-6^{\text {th }}$ International Conference on Management, Enterprise and Benchmarking, May 30-31, 2008 Budapest, Hungary.

Tech, J. E. T. (2020), “The Influence of Online Food Delivery Service Quality on Customer Satisfaction and Customer Loyalty: The Role of Personal Innovativeness", Journal of Environmental Treatment Techniques, Vol. 8, No. 1, pp. 6-12.

Tuzovic, S. (2008), "Investigating the concept of potential quality: An exploratory study in the real estate industry", Managing Service Quality, Vol. 18, No. 3, pp. 255-271.

Tweneboah-Koduah, E.Y. and Farley, A.Y.D. (2016), "Relationship between Customer Satisfaction and Customer Loyalty in the Retail Banking Sector of Ghana", International Journal of Business and Management, Vol. 11, No. 1, pp. 249- 262.

Uncles, M.D., Dowling, G.R. and Hammond, K. (2003), "Customer loyalty and customer loyalty programs", Journal of Consumer Marketing, Vol. 20 No. 4, pp. 294-316. 